\title{
ANALISIS ALGORITMA KLASIFIKASI DAN ASOSIASI TERHADAP ATRTIBUT DATA PELAKU USAHA MIKRO KECIL DAN MENENGAH (UMKM)
}

\author{
Fakultas Teknologi Informasi \\ Universitas Islam Kalimantan Muhammad Arsyad Al Banjari Banjarmasin \\ Mokhamad Ramdhani Raharjo, S.Kom., M.Kom \\ ramdhanihouse@gmail.com
}

\begin{abstract}
ABSTRAK
UMKM merupakan pelaku bisnis yang bergerak pada berbagai bidang usaha untuk kepentingan masyarakat. Pada saat ini UMKM dianggap sebagai cara yang efektif dalam pengentasan kemiskinan. UMKM pada saat ini sebagian besar dihadapkan dalam suatu permasalahan yang membuat usaha tersebut menjadi tidak lancar atau tidak berkembang, hal ini disebabkan oleh faktor permodalan, pengembangan kemitraan, promosi, pengembangan usaha dan sumber daya manusia. Penerapan ilmu datamining untuk menganalisa atribut pelaku usaha UMKM diperlukan untuk membantu permasalahan tersebut dengan melihat hasil uji algoritma klasifikasi yaitu Decision Tree dan CHAID serta algoritma Asosiasi Tertius. Pemberian bantuan terhadap pelaku usaha UMKM dengan cara memberi pelatihan strategi pemasaran dan penggunaan sarana prasarana penjualan sesuai proporsi masing-masing pelaku usaha dengan melihat hasil analisa algoritma datamining.

Hasil pengujian menunjukan bahwa perbandingan algoritma klasifikasi Decision Tree dengan CHAID akurasi tertinggi $90.49 \%$ untuk algoritma Decision Tree sedangkan $89.51 \%$ untuk algoritma CHAID. Sedangkan pengujian algoritma asosiasi menggunakan algoritma Tertius mendapatkan kombinasi asosiasi antara nilai atribut umur, jenis kelamin, dan pekerjaan.
\end{abstract}

Kata kunci : Klasifikasi, Asosiasi, UMKM, Decision Tree, CHAID, Tertius 


\section{PENDAHULUAN}

Pada saat ini usaha mikro, kecil dan menengah (UMKM) memiliki peranan yang sangat vital didalam pembangunan dan pertumbuhan ekonomi, tidak hanya di negaranegara berkembang seperti Indonesia tetapi juga di negara-negara maju.UMKM memiliki peran dalam pertumbuhan pembangunan dan ekonomi, UMKM juga berperan sangat penting dalam mengatasi masalah pengangguran yang terjadi di suatu Negara. Pertumbuhan usaha mikro merupakan sumber pertumbuhan kesempatan kerja dan pendapatan dengan banyak menyerap tenaga kerja. Dalam hal ini UMKM secara tidak langsung memiliki peran strategis dalam upaya memerangi kemiskinan dan pengangguran dalam suatu Negara. Akan tetapi pelaku UMKM pada saat ini sebagian besar dihadapkan dalam suatu permasalahan yang membuat usaha tersebut menjadi tidak lancar atau tidak berkembang, hal ini disebabkan oleh faktor permodalan, pengembangan kemitraan, promosi, pengembangan usaha dan sumber daya manusia pelaku UMKM itu sendiri. Permasalahan tersebut seharusnya bisa diatasi dengan memberikan pelatihan terhadap strategi pelaku usaha UMKM mengingat SDM setiap orang berbeda-beda dalam merancangan strategi pemasaran apalagi di era digital sekarang yang sangat maju begitu pesat.

\section{RUMUSAN MASALAH}

Dengan melihat masalah tersebut bagaimana menganalisis algoritma klasifikasi dan asosiasi terdapat atribut atau variabelvariabel data pelaku UMKM guna mendapatkan suatu solusi untuk mengatasi permasalahan yang dihadapi.

\section{TUJUAN PENELITIAN}

Penelitian ini bertujuan untuk menerapkan algoritma klasifikasi Decision Tree dan CHAID dengan membandingkan hasil akurasi serta menerapakan algoritma Tertius untuk mengetahui kerterkaitan atribut variabel pada pelaku UMKM.

\section{TARGET LUARAN DAN MANFAAT PENELITIAN}

Target luaran dalam penelitian ini untuk mempelajari dan menganalisa klasifikasi dan hubungan atribut (Asosiasi) terhadap data UMKM.

\section{METODE PENELITIAN}

Proses analisis klasifikasi dan asosiasi terhadap atribut atau variabel UMKM. Sampel data uji menggunakan data UMKM Kabupaten Banjar. Proses tersebut terdiri dari beberapa tahapan sebagai berikut :

1. Seleksi atribut

2. Transformasi data

3. Klasifikasi dan Asosiasi

4. Kesimpulan

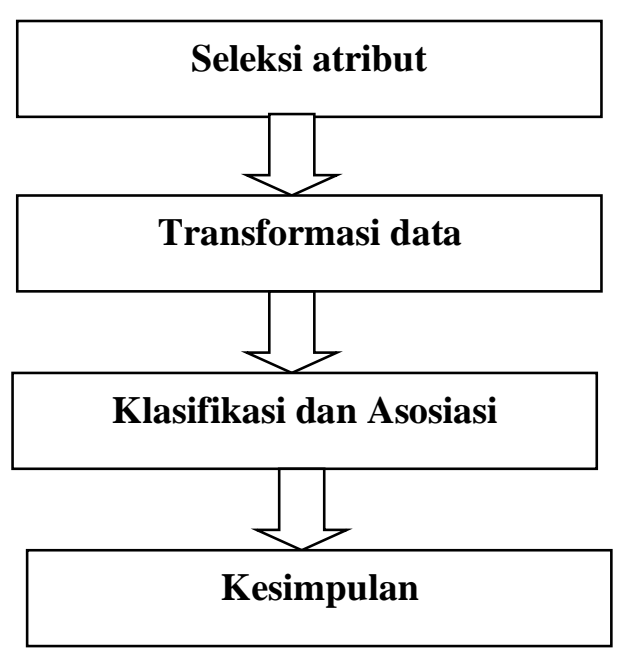

Gambar 1 Alur proses penelitian

\section{Seleksi Atribut}

Proses seleksi atribut dilakukan dengan menghilangkan beberapa atribut yang tidak memilki pengaruh terhadap proses analisis terhadap algoritma yang digunakan.

Atribut yang digunakan dalam analisa yaitu :

- Status Usaha (X1)

- Klasifikasi Usaha (X2)

- Tempat Lahir (X3)

- Umur (X4)

- Jenis Kelamin (X5)

- Pendidikan (X6) 
- Pekerjan (X7)

- Status Menikah (X8)

- Kecamatan (X9)

Atribut yang tidak digunakan dalam proses analisa yaitu :

- Modal

- Golongan Darah

- Agama

- Status Nikah

- Nama Ibu

- Nama Ayah

- Alamat

\section{Transformasi Data}

Proses mengubah data yang kompleks dengan tidak menghilangkan isi, sehingga lebih mudah diolah.

\section{- Normalisasi}

Mengelompokan data umur menjadi berapa kelompok usia dewasa awal, dewasa akhir, lansia awal, lansia akhir, manula dan dewasa akhir.

\section{- Generelisasi}

Perubahan nilai atribu pekerjaan pada pelaku UMKM menjadi Perdagangan dan Reparasi, Tenaga Kasar/Tenaga Kebersihan, Tenaga Pengolahan dan Kerajinan, Teknisi/Tenaga Profesional, Pekerjaan Lainnya dan Pejabat Legislatif/Pejabat Tinggi Pemerintahan.

\section{Klasifikasi dan Asosiasi}

Proses uji coba klasifikasi data UMKM dilakukan dengan membandingkan hasil akurasi dua algoritma yang digunakan yaitu, Decision Tree dan CHAID, sedangkan uji coba Asosiasi dengan melihat hubungan antar atribut yang dihasilkan dari algoritma Tertius.

\section{Kesimpulan}

Proses penarikan kesimpulan terhadap hasil uji algoritma klasifikasi dan asosiasi.

\section{EKSPERIMEN DAN PENGUJIAN METODE}

\section{Pengujian Klasifikasi}

Melakukan perbandingan pengujian dengan teknik fold cross validasi dari data uji terhadap dua algoritma yang digunakan. Cross Validation merupakan salah satu teknik untuk menilai atau memvalidasi keakuratan sebuah model yang dibangun berdasarkan dataset tertentu. Pembagian data uji pada teknik cross validasi membagi mulai dari 2,3,4,5,6,7,8,9 dan 10 data uji.

\section{- Pengujian data terhadap algoritma Decision Tree}

Tabel 1. Pengujian Decision Tree

\begin{tabular}{|c|c|}
\hline \multicolumn{2}{|c|}{ DECISITION TREE } \\
\hline K-Fold & Akurasi \\
\hline 2 & $90.49 \%$ \\
\hline 3 & $90.49 \%$ \\
\hline 4 & $90.49 \%$ \\
\hline 5 & $89.31 \%$ \\
\hline 6 & $90.49 \%$ \\
\hline 7 & $88.73 \%$ \\
\hline 8 & $87.36 \%$ \\
\hline 9 & $89.41 \%$ \\
\hline 10 & $89.02 \%$ \\
\hline
\end{tabular}

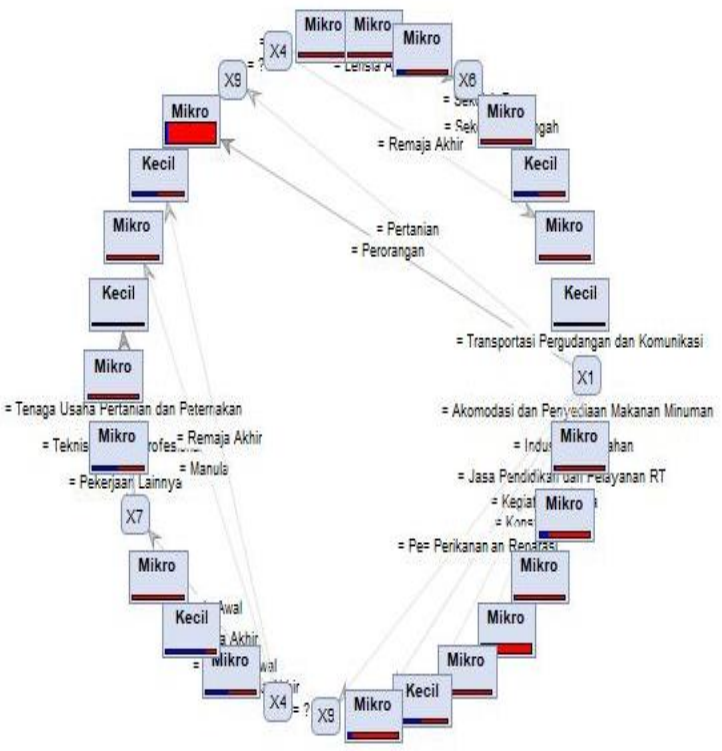


Gambar 1. Hasil pengujian Decision Tree

\section{- Pengujian data terhadap algoritma Chaid}

Gambar 2. Hasil pengujian

CHAID

\section{- Pengujian data terhadap} algoritma Tertius (Asosiasi)

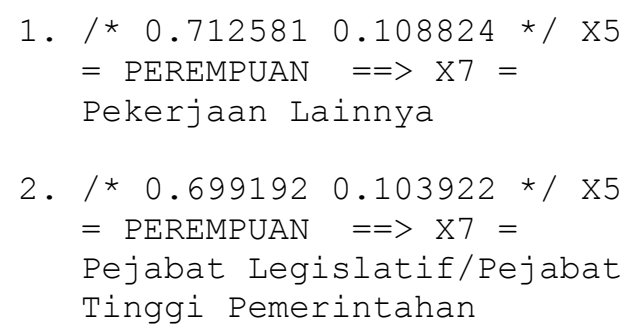

Tabel 2. Pengujian CHAID

\begin{tabular}{|c|l|}
\hline \multicolumn{2}{|c|}{ CHAID } \\
\hline K-Fold & Akurasi \\
\hline 2 & $88.33 \%$ \\
\hline 3 & $89.12 \%$ \\
\hline 4 & $89.41 \%$ \\
\hline 5 & $89.12 \%$ \\
\hline 6 & $88.43 \%$ \\
\hline 7 & $89.02 \%$ \\
\hline 8 & $88.83 \%$ \\
\hline 9 & $89.51 \%$ \\
\hline 10 & $89.02 \%$ \\
\hline
\end{tabular}

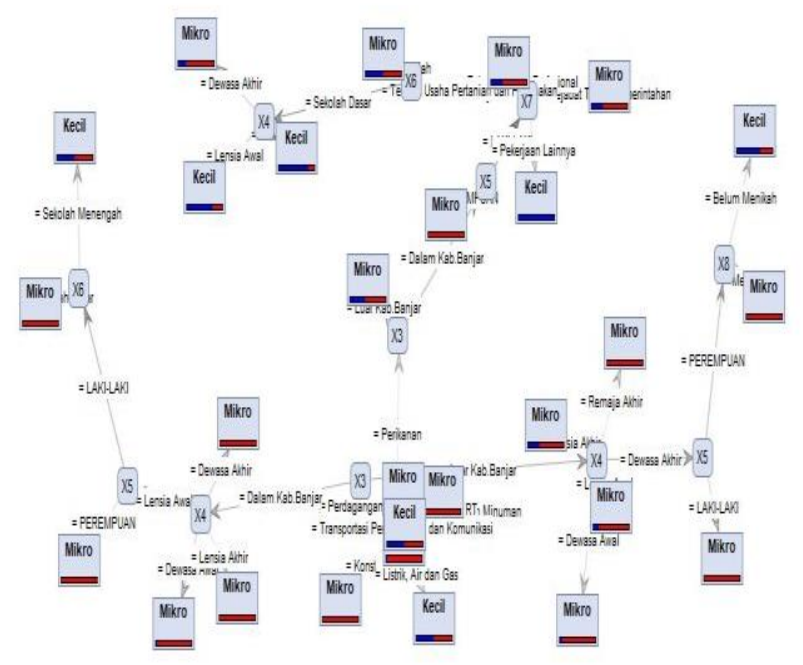

3. /* $0.6759880 .104902 * / \times 5$ $=$ PEREMPUAN $==>\mathrm{X} 7=$ Tenaga Pengolahan dan Kerajinan

4. /* $0.6702610 .080392 * / \times 5$ $=$ PEREMPUAN $==>\mathrm{X} 7=$ Tenaga Kasar/Tenaga Kebersihan/Tenaga Ybdi

5. /*0.5198490.100980*/ X5 $=$ PEREMPUAN $==>\mathrm{X} 7=$ Tenaga Usaha Pertanian dan Peternakan

6. /* $0.4639550 .063725 * / \times 5$ $=$ PEREMPUAN $==>\mathrm{X} 4=$ Dewasa Akhir or $\mathrm{X} 7=$ Pekerjaan Lainnya

7. /*0.4574950.059804*/ X5 $=$ PEREMPUAN $==>\mathrm{X} 4=$ Dewasa Akhir or $\mathrm{X} 7=$ Pejabat Legislatif/Pejabat Tinggi Pemerintahan

8. /*0.4528830.061765*/ X5 $=$ PEREMPUAN $==>\mathrm{X} 4=$ Manula or $\mathrm{X} 7=$ Pekerjaan Lainnya

9. /*0.450005 $0.057843 * / \times 5$ $=$ PEREMPUAN $==>\mathrm{X} 4=$ Manula or $\mathrm{X} 7=$ Pejabat Legislatif/Pejabat Tinggi Pemerintahan

10. / * $0.4499800 .060784 * /$ $\mathrm{X} 5=$ PEREMPUAN $==>\mathrm{X} 4=$

Jurnal Ilmiah "Technologia" 
Dewasa Akhir or $\mathrm{X} 7$ = Tenaga

Pengolahan dan Kerajinan

Jumlah hipotesis yang dipertimbangkan: 5386 Jumlah hipotesis yang dieksplorasi: 512

\section{IMPLEMENTASI PENELITIAN}

Data hasil perbandingan algoritma klasifikasi dan perhitungan asosiasi disimpulkan bahwa metode Decision Tree mendapatkan hasil akurasi tertinggi dengan nilai $90.49 \%$ dengan folds cross validation ke 2,3,4 dan 6. Sedangkan untuk algoritma Chaid nilai akurasi tertinggi dengan nilai $89.51 \%$ pada folds cross validation ke 9 . Untuk pengujian algoritma Tertius menghasilkan hubungan atribut yang berhubungan yaitu umur, jenis kelamin dan pekerjaan serta jumlah hipotesis yang dipertimbangkan 5386 dan jumlah hipotesis yang dieksplorasi 512.

\section{PENUTUP}

\section{KESIMPULAN}

Berdasarkan hasil analisis algoritma klasifikasi dan asosiasi maka diperoleh kesimpulan sebagai berikut :

1. Penerapan algoritma Decision Tree dengan folds cross validation mendapatkan nilai akurasi tertinggi dari pada algoritma CHAID. Akurasi tertinggi didapatkan pada data pengujian ke 2,3,4 dan 6. Sedangkan algoritma CHAID menghasilkan akurasi tertinggi pada data pengujian ke 9 dengan nilai akurasi 89.51\% untuk mengklasifikan UMKM antara jenis usaha Kecil dan Mikro.

2. Penerapan algoritma Tertius untuk menganalisa hubungan antar atribut data UMKM didapatkan bahwa atribut jenis kelamin, umur, dan pekerjaan mempunyai keterkaitan terhadap data UMKM.

Jurnal Ilmiah "Technologia"

\section{DAFTAR PUSTAKA}

[1] I. P. Rudi, “ Penerapan Data mining Pada Penyewaan FIlm Di Ultra Disk Cabang Antapani Menggunakan Metode Association Rules", 2014

[2] Santosa Budi, “ Data mining, Teknik Pemanfaatan Data Untuk Keperluan Bisnis”, Graha Ilmu, Yogyakarta, 2007.

[3] Kusrini and E. T. Luthfi, "Algoritma Data Mining”, Andi Offset, Yogyakarta, 2009.

[4] Prasetyo, P. Eko, 1998. Strategi Pengembangan Industri Kecil Kerajinan Bambu Sebagai Upaya Mendukung Program Pengentasan Kemiskinan. Laporan Penelitian, Kopertis V Yogyakarta.

[5] Partomo, Titik S., dan Abd. Rachman S., 2004. Ekonomi Skala Kecil/Menengah dan Koperasi. Ghalia Indonesia, Jakarta.

[6] Yustika, Ahmad Erani, 2005. Perekonomian Indonesia; Deskripsi, Preskripsi, dan Kebijakan. Bayu Media, Malang.

[7] Liu, C., dan Jiang, Q., 2009, Mixed Financial Forecasting Index System Construct and Financial Forecasting Study on the C4.5 Decision Tree, 
International Conference on

Management and Service Science,

MASS '09, pp.1-4, 20-22 Sept. 2009 